\title{
Effects of Dietary Tongmai Granule Residue Supplementation on Growth Performance, Nutrient Digestibility, Blood Biochemical Parameters and Rumen Fermentation in Sheep
}

\section{Pei Zhang}

Jilin Agricultural University

Shiwen Sun

Jilin Agricultural University

Wenge Cheng

Institute of Biology, Jilin province

Abedin Abdallah

Jilin Agricultural University

Zewei Sun ( $\nabla$ sunzewei@jlau.edu.cn )

Jilin Agricultural University https://orcid.org/0000-0001-9880-205X

Qingzhen Zhong

Jilin Agricultural University

Original article

Keywords: Tongmai granules, nutrient digestibility, rumen fermentation, growth performance

Posted Date: August 25th, 2020

DOI: https://doi.org/10.21203/rs.3.rs-60214/v1

License: (c) (i) This work is licensed under a Creative Commons Attribution 4.0 International License.

Read Full License 


\section{Abstract}

The purpose of this study was to investigate the effects of Tongmai granule residue (TGR) on the growth performance, apparent nutrient digestibility, blood biochemical parameters, and rumen fermentation in Doper x Small Tail Han hybrid sheep. Twenty-four healthy female lambs (6-7 months of age; $29.64 \pm$ $1.80 \mathrm{~kg}$ initial body weight) were randomly divided into 3 groups and fed for 75 days. The control group was fed a commercial concentrate and the other groups were fed diets supplemented with $10 \%$ and $15 \%$ TGR respectively. Dietary $15 \%$ TGR supplementation decreased average daily gain, apparent digestibility of neutral detergent fiber, but increased the feed conversion ratio, apparent digestibility of crude fat and organic matter in lambs $(P<0.05)$. The 10\% TGR group significantly increased the apparent digestibility of organic matter $(P<0.05)$. Dietary supplementation of $10 \%$ and $15 \%$ TGR significantly increased serum high density lipoprotein cholesterol (HDL-C) content on day 15, IgG content on day 30 , and IgA content on day 60 of the feeding period $(P<0.05)$. Dietary supplementation of $15 \%$ TGR significantly increased the content of IgA on the 30th day $(P<0.05)$, and significantly decreased blood urea nitrogen (BUN) on the 30th day $(P<0.05)$ of the feeding period. TGR at $15 \%$ significantly decreased the contents of acetic acid, propionic acid, butyric acid, and total volatile fatty acids (TVFA) in the rumen $(P<0.05)$, and significantly increased the $\mathrm{pH}, \mathrm{NH} 3-\mathrm{N}$ concentration, and acetic acid: propionic acid ratio $(P<0.05)$. The results suggest that, the addition of TGR to diet can improve the apparent digestibility of crude fat and organic matter, and improve the anti-atherosclerosis ability and immune function of Doper $x$ Small Tail Han hybrid female lambs. The dietary addition of 10\% TGR yielded the best feeding effect in this experiment.

\section{Introduction}

Chinese herbal medicine, is a valuable medical resource in China known for its numerous functions in health care such as prevention and treatment of diseases. For over 2000 years, herbal medicines have been used in China, as feed additives in animal husbandry to promote animal production and health. These herbs provide animals with nutrients such as peptides, proteins, essential amino acids, starch, oligosaccharides, vitamins, fatty acids, and organic trace minerals, and as well, possess many bioactive ingredients with antibacterial activity, immune enhancement, and stress reduction properties (Wang et al., 1998; Guo et al., 2004). Also, previous studies on Chinese herbs as feed additives have shown that these herbs can modulate the immune response, nutritional metabolism, and intestinal health of foodproducing animals (Gong et al., 2014).

In recent years, the Chinese herbal medicine industry has been developing rapidly due to the continuous increase in the usage of Chinese herbal medicine resources. This results in an increased yield in Chinese herbal medicine residue. Moreover, due to poor extraction processes and extraction efficiency, the herbal residue still contains nutrients such as cellulose, hemicellulose and lignin, as well as $30 \%-50 \%$ medicinally active ingredients (Wang et al., 2010; Meng et al., 2017). For example, the contents of calycosin and formononetin in Radix Astragali residue were $75.16 \%$ and $77.06 \%$, respectively (Chen et al., 2011). Furthermore, Salviae Miltiorrhizae Radix residue contains 3.62\% tanshinone IIA, $2.56 \%$ 
Chinese herbal medicine residue could be further utilized. Zhu et al. (2016) suggested that Astragalus residue improved the immunity and digestion ability of white ducks resulting in a corresponding increase in body weight and weight of immune organs. In another study, it was shown that herbal residue fermentation supernatant (Jianweixiaoshi tablets) inhibits urease activity, slows down cell infiltration in the gastric area, reduces the level of gastric inflammatory cytokines IL-6, IL-8 and TNF-a, and helps to improve a disturbed microbiota, indicating strong potential in treating Helicobacter pylori infections (Meng et al., 2017).

Tongmai formula is a popular Chinese herbal medicine formula composed of three traditional Chinese herbal medicines: Chuanxiong rhizoma (rhizomes of Ligusticum chuanxiong), Puerariae lobatae Radix (roots of Pueraria lobata) and Salviae Miltiorrhizae Radix (roots of Salvia miltiorrhiza) in a ratio of 1:1:1. It is widely used in the treatment of cerebrovascular and cardiovascular diseases, such as high blood lipids, myocardial infarction and atherosclerosis (Wu et al., 2017). So far, research on Tongmai formula is mainly focused on its chemical composition. As such, no research has been conducted on the application of TGR in sheep production. Therefore, the main objective of the present study was to determine the effects of TGR on the growth performance, apparent nutrient digestibility, blood biochemical parameters and rumen fermentation in Doper $\times$ Small Tail Han hybrid sheep, and to explore the feasibility of TGR as a ruminant feed additive.

\section{Materials And Methods}

All experimental protocols involving animals were approved by the Institutional Committee for Animal use and Ethics of the College of Animal Nutrition and Feed Science of Jilin Agricultural University and also in agreement with the provincial rules and regulations.

\section{Tongmai Granules}

The fresh Tongmai Granules which mainly include Salvia miltiorrhiza, Ligusticum chuanxiong and Pueraria lobata were obtained from Xiuzheng Pharmaceutical Co. Ltd. The residue was air-dried and then pulverized to pass through a 2-mm screen.

\section{Animals and feeding management}

A total of 24 Doper $x$ Small Tail Han hybrid ewes with average weight of $29.64 \pm 1.80 \mathrm{~kg}$ were randomly allocated to 3 treatment groups with 8 repetitions (8 sheep in each treatment) in a randomized complete block design based on body weight. Each group was fed a diet containing different levels of TGR; $0 \%$, 10\%, and 15\% TGR. The diets were formulated according to the National Research Council (NRC, 2010) recommendations for an average daily weight gain of $200 \mathrm{~g} /$ day (Table 1). The experiment lasted for 75 days with an adaptation period of 15 days, during which time; the animals were weighed, tagged and 
drinking water. Feed and water troughs were cleaned daily and the pen kept ventilated and hygienic at all times. 
Table 1

Ingredients and chemical composition of the experimental diets ( $\mathrm{g} / \mathrm{kg} \mathrm{DM})$

\begin{tabular}{|c|c|c|c|}
\hline \multirow[t]{2}{*}{ Items } & \multicolumn{3}{|l|}{$\operatorname{Diet}^{1}$} \\
\hline & Control & $10 \%$ TGR & $15 \%$ TGR \\
\hline \multicolumn{4}{|l|}{ Ingredients } \\
\hline Guinea grass & 300 & 300 & 300 \\
\hline Maize straw & 100 & 100 & 100 \\
\hline Tongmai granule residues & 0.00 & 100 & 150 \\
\hline Molasses & 18 & 18 & 18 \\
\hline Corn & 255 & 210 & 204 \\
\hline Distillers dried grains with solubles & 109 & 95 & 93 \\
\hline Corn gluten meal & 175 & 133 & 90 \\
\hline Premix ${ }^{2}$ & 4 & 4 & 4 \\
\hline Urea & 3 & 5 & 6 \\
\hline Sodium chloride & 8 & 8 & 8 \\
\hline Calcium carbonate & 15 & 15 & 15 \\
\hline Dcicaluium phosphate & 4 & 4 & 4 \\
\hline Sodium bicarbonate & 8 & 7 & 6 \\
\hline \multicolumn{4}{|l|}{ Nutrient content ${ }^{3}$} \\
\hline Dry matter ( $\mathrm{g} / \mathrm{kg}$ fresh weight) & 886 & 888 & 889 \\
\hline Crude protein & 124 & 123 & 123 \\
\hline Metabolizable energy (MJ/kg) & 99 & 97 & 96 \\
\hline Neutral detergent fibre & 418 & 457 & 464 \\
\hline Acid detergent fibre & 256 & 272 & 288 \\
\hline Calcium & 8 & 8 & 9 \\
\hline
\end{tabular}

${ }^{1}$ Tongmai granule residues.

${ }^{2}$ Supplied per kg of diets: VA 15000 IU, VD 2000 IU, VE 55 IU, Fe 50 mg, Co 0.2 mg, Cu 12.0 mg, Se $0.5 \mathrm{mg}, \mathrm{Mn} 50 \mathrm{mg}, \mathrm{l} 0.55 \mathrm{mg}$, Zn $25 \mathrm{mg}$. 


\begin{tabular}{|c|c|c|c|}
\hline \multirow[t]{2}{*}{ Items } & \multicolumn{3}{|l|}{$\operatorname{Diet}^{1}$} \\
\hline & Control & $10 \%$ TGR & $15 \%$ TGR \\
\hline Phosphorus & 5 & 4 & 4 \\
\hline \multicolumn{4}{|c|}{${ }^{1}$ Tongmai granule residues. } \\
\hline \multicolumn{4}{|c|}{$\begin{array}{l}2 \text { Supplied per kg of diets: VA } 15000 \text { IU, VD } 2000 \text { IU, VE } 55 \text { IU, Fe } 50 \text { mg, Co } 0.2 \text { mg, Cu } 12.0 \text { mg, Se } \\
0.5 \text { mg, Mn } 50 \text { mg, I } 0.55 \text { mg, Zn } 25 \text { mg. }\end{array}$} \\
\hline
\end{tabular}

\section{Sampling and analysis}

The animals were weighed before the morning feeding on the first and last days of the feeding period, and the amount of feed supplied and rejected were recorded per animal. The average daily gain (ADG), average daily feed intake (ADFI), and feed conversion ratio (FCR) were calculated.

On the 65th day of the feeding period, the test sheep were transferred to single metabolic cages for metabolic test. Left over feed and total faecal samples were collected before the morning feeding from each animal from day 68 to 74 of the feeding period. Samples of approximately $10 \%$ of the total faeces were taken and to them were added $10 \% \mathrm{H}_{2} \mathrm{SO}_{4}$. At the end of the metabolic test period, the samples were composited, dried at $65^{\circ} \mathrm{C}$ for $72 \mathrm{~h}$, weighed, ground to pass through a $1 \mathrm{~mm}$ screen and then analysed for crude protein (CP), ether extract (EE), neutral detergent fibre (NDF), acid detergent fibre (ADF) and organic matter $(\mathrm{OM})$.

Blood samples were collected from the jugular vein of each sheep into $5 \mathrm{ml}$ heparinized collection tubes before the morning feeding on days $15,30,45$ and 60 of the experiment. The blood samples were centrifuged at $3500 \mathrm{xg}$ for $10 \mathrm{~min}$ at $4^{\circ} \mathrm{C}$. The serum was obtained and stored at $-80^{\circ} \mathrm{C}$ until further analysis. Serum blood urea nitrogen (BUN), glucose (GLU), total cholesterol (TC), triglycerides (TG), total protein (TP), high-density lipoprotein cholesterol (HDL-C), albumin (ALB), low-density lipoprotein cholesterol (LDL-C) and globulin (GLB) concentrations were determined on a fully automatic biochemical analyzer using a standard commercial kit (Jilin Jinyu Medical Laboratory Co., Ltd., Changchun, China). The concentrations of immunoglobulin $\mathrm{G}(\mathrm{IgG})$, immunoglobulin $\mathrm{M}(\operatorname{Ig} M)$ and immunoglobulin $\mathrm{A}(\lg \mathrm{A})$ in serum were analyzed using commercial ELISA kits supplied by the Nanjing Jian Cheng Bioengineering Institute (Nanjing, China).

Ruminal fluid samples were obtained from the rumen immediately after the sheep were slaughtered. Ruminal $\mathrm{pH}$ was measured using a portable type $\mathrm{pH}$ meter (S20K,METTLER TOLEDO Switzerland) during rumen content collection. The samples were then filtered through four layers of cheesecloth and the extracts were collected into $50 \mathrm{~mL}$ centrifuge tubes and then centrifuged at $10,000 \times \mathrm{g}$ for $15 \mathrm{~min}$ at $4{ }^{\circ} \mathrm{C}$. Loading [MathJax]/jax/output/CommonHTML/jax.js quently stored at $-80^{\circ} \mathrm{C}$ until analyses for ammonia nitrogen 
$\left(\mathrm{NH}_{3}-\mathrm{N}\right)$ and volatile fatty acids (VFA) concentrations. The $\mathrm{NH}_{3}-\mathrm{N}$ concentration was determined by spectrophotometer colorimetry, and the VFA concentration was measured by gas chromatography.

\section{Statistical analysis}

Data were analysed by analysis of variance, using the General Linear Model procedure of SPSS 23.0 (SPSS Inc., Chicago, IL, USA). The means of each trait were compared by Tukey multiple comparisons and presented with the standard error of the mean. Differences were considered statistically significant if $P \leq 0.05$.

\section{Results}

\section{Growth performance}

The effect of dietary TGR on growth performance in Doper $x$ Small Tail Han sheep is presented in Table 2. The growth performance of sheep was not improved by dietary TGR supplementation. When $15 \%$ TGR was added, the average daily gain decreased significantly $(P<0.05)$, and the feed conversion ratio increased significantly $(P<0.05)$. There was no significant difference in the average daily feed intake between the sheep in all dietary groups $(P>0.05)$.

Table 2

Effects of dietary supplementation of Tongmai granule residue on growth performance in sheep

\begin{tabular}{|c|c|c|c|c|c|}
\hline \multirow[t]{2}{*}{ Items $^{1}$} & \multicolumn{3}{|l|}{ Diet } & \multirow[t]{2}{*}{ SEM } & \multirow[t]{2}{*}{$P$-Value } \\
\hline & Control & $10 \%$ TGR & $15 \%$ TGR & & \\
\hline Initial weight (kg) & 33.2 & 31.5 & 31.3 & 0.72 & 0.52 \\
\hline Final weight (kg) & 41.4 & 40.1 & 38.6 & 0.72 & 0.31 \\
\hline$A D G(g / d)$ & $137^{a}$ & $144^{a}$ & $121^{b}$ & 3.95 & 0.02 \\
\hline $\operatorname{ADFI}(\mathrm{kg} / \mathrm{d})$ & 1.51 & 1.46 & 1.50 & 0.03 & 0.71 \\
\hline FCR & $11.05^{\mathrm{b}}$ & $10.2^{b}$ & $12.5^{\mathrm{a}}$ & 0.36 & 0.01 \\
\hline \multicolumn{6}{|c|}{ a-b Means within a row with different letters differ $(P<0.05)$. } \\
\hline
\end{tabular}

\section{Apparent nutrient digestibility}

As shown in Table 3, dietary TGR had no significant effect on the apparent digestibility of CP and ADF ( $P$ Loading [MathJax]/jax/output/CommonHTML/jax.js eased the apparent digestibility of OM $(P<0.05)$ while $15 \%$ 
TGR significantly increased the apparent digestibility of EE and OM $(P<0.05)$, and significantly decreased that of NDF $(P<0.05)$.

Table 3

Effects of dietary supplementation of Tongmai granule residue on apparent nutrient digestibility in sheep

\begin{tabular}{|c|c|c|c|c|c|}
\hline \multirow[t]{2}{*}{ Items $^{1}(\mathrm{~g} / \mathrm{kg})$} & \multicolumn{3}{|l|}{ Diet } & \multirow[t]{2}{*}{ SEM } & \multirow[t]{2}{*}{$P$-Value } \\
\hline & Control & $10 \%$ TGR & $15 \%$ TGR & & \\
\hline $\mathrm{CP}$ & 701 & 684 & 672 & 6.16 & 0.15 \\
\hline $\mathrm{EE}$ & $556^{\mathrm{b}}$ & $626^{a b}$ & $694^{a}$ & 22.9 & 0.03 \\
\hline $\mathrm{OM}$ & $504^{b}$ & $638^{a}$ & $581^{a}$ & 19.0 & $<0.01$ \\
\hline ADF & 426 & 417 & 381 & 18.8 & 0.63 \\
\hline NDF & $668^{a}$ & $617^{a b}$ & $594^{\mathrm{b}}$ & 13.7 & 0.04 \\
\hline
\end{tabular}

${ }^{\mathrm{a}-\mathrm{b}}$ Means within a row with different letters differ $(P<0.05)$.

${ }^{1} \mathrm{CP}$, crude protein; $\mathrm{EE}$, ether extract; $\mathrm{OM}$, organic matter; $\mathrm{ADF}$, acid detergent fibre; NDF, neutral detergent fibre.

\section{Blood biochemical parameters}

The effect of TGR on the blood biochemical parameters of sheep is summarized in Tables 4-7. On day 15 , dietary supplementation of $10 \%$ TGR and $15 \%$ TGR significantly increased the concentrations of HDL$C$ in serum $(P<0.05)$, and had no significant effect on other biochemical parameters $(P>0.05)$. However, the concentrations of GLU, BUN, TG, TP, and GLB decreased, and the concentrations of ALB, IgG, and IgM increased with an increase in TGR addition $(P>0.05)$. 
Table 4

Effects of dietary supplementation of Tongmai granule residue on blood biochemical parameters in sheep $(15 d)$

\begin{tabular}{|c|c|c|c|c|c|}
\hline \multirow{2}{*}{ Items $^{1}$} & \multicolumn{3}{|l|}{ Diet } & \multirow[t]{2}{*}{ SEM } & \multirow[t]{2}{*}{$P$-Value } \\
\hline & Control & $10 \%$ TGR & $15 \%$ TGR & & \\
\hline $\mathrm{GLU}(\mathrm{mmol} / \mathrm{L})$ & 4.02 & 3.95 & 3.85 & 0.05 & 0.36 \\
\hline BUN (mmol/L) & 6.58 & 5.56 & 5.55 & 0.25 & 0.15 \\
\hline TG $(\mathrm{mmol} / \mathrm{L})$ & 0.40 & 0.39 & 0.36 & 0.01 & 0.35 \\
\hline TC (mmol/L) & 2.03 & 2.15 & 2.10 & 0.04 & 0.52 \\
\hline $\mathrm{HDL}-\mathrm{C}(\mathrm{mmol} / \mathrm{L})$ & $1.10^{b}$ & $1.26^{\mathrm{a}}$ & $1.38^{\mathrm{a}}$ & 0.04 & 0.01 \\
\hline LDL-C (mmol/L) & 0.64 & 0.69 & 0.63 & 0.02 & 0.59 \\
\hline $\mathrm{TP}(\mathrm{g} / \mathrm{L})$ & 67.4 & 66.5 & 65.2 & 0.80 & 0.56 \\
\hline ALB $(g / L)$ & 34.4 & 35.3 & 35.7 & 0.36 & 0.32 \\
\hline GLB (g/L) & 33.00 & 31.1 & 29.5 & 0.82 & 0.22 \\
\hline $\lg A(u g / m L)$ & 56.5 & 54.6 & 57.7 & 1.15 & 0.59 \\
\hline $\lg G(\mathrm{ug} / \mathrm{mL})$ & 109 & 126 & 127 & 4.24 & 0.15 \\
\hline $\lg M(u g / m L)$ & 449 & 462 & 463 & 7.09 & 0.71 \\
\hline \multicolumn{6}{|c|}{ a-b Means within a row with different letters differ $(P<0.05)$. } \\
\hline \multicolumn{6}{|c|}{$\begin{array}{l}{ }^{1} \mathrm{GLU} \text {, glucose; BUN, blood urea nitrogen; TG, triglyceride; TC, total cholesterol; } \mathrm{HDL}-\mathrm{C} \text {, high-density } \\
\text { lipoprotein cholesterol; } \mathrm{LDL}-\mathrm{C} \text {, low-density lipoprotein cholesterol; TP, total protein; } \mathrm{ALB} \text {, albumin; } \mathrm{GLB} \text {, } \\
\text { globulin; IgA, immunoglobulin A; IgG, immunoglobulin G; IgM, immunoglobulin M. }\end{array}$} \\
\hline
\end{tabular}


Table 5

Effects of dietary supplementation of Tongmai granule residue on blood biochemical parameters in sheep (30d)

\begin{tabular}{|c|c|c|c|c|c|}
\hline \multirow[t]{2}{*}{ Items $^{1}$} & \multicolumn{3}{|l|}{ Diet } & \multirow[t]{2}{*}{ SEM } & \multirow[t]{2}{*}{$P$-Value } \\
\hline & Control & $10 \%$ TGR & $15 \%$ TGR & & \\
\hline GLU (mmol/L) & 4.09 & 3.74 & 3.99 & 0.12 & 0.51 \\
\hline BUN (mmol/L) & $7.18^{a}$ & $6.52^{\mathrm{ab}}$ & $6.13^{b}$ & 0.17 & 0.03 \\
\hline TG (mmol/L) & 0.38 & 0.40 & 0.37 & 0.01 & 0.63 \\
\hline $\mathrm{TC}(\mathrm{mmol} / \mathrm{L})$ & 1.82 & 1.90 & 1.82 & 0.04 & 0.70 \\
\hline $\mathrm{HDL}-\mathrm{C}(\mathrm{mmol} / \mathrm{L})$ & 1.29 & 1.28 & 1.36 & 0.03 & 0.59 \\
\hline LDL-C (mmol/L) & 0.51 & 0.58 & 0.54 & 0.02 & 0.39 \\
\hline $\mathrm{TP}(\mathrm{g} / \mathrm{L})$ & 67.2 & 66.7 & 64.5 & 1.04 & 0.57 \\
\hline $\operatorname{ALB}(\mathrm{g} / \mathrm{L})$ & 36.0 & 36.6 & 37.2 & 0.28 & 0.25 \\
\hline $\operatorname{GLB}(\mathrm{g} / \mathrm{L})$ & 31.5 & 30.06 & 28.03 & 1.03 & 0.43 \\
\hline $\lg A(u g / m L)$ & $56.9^{b}$ & $60.9^{a b}$ & $64.90^{\mathrm{a}}$ & 1.34 & 0.04 \\
\hline $\operatorname{lgG}(\mathrm{ug} / \mathrm{mL})$ & $117^{b}$ & $158^{\mathrm{a}}$ & $152^{\mathrm{a}}$ & 7.44 & 0.03 \\
\hline $\operatorname{lgM}(\mathrm{ug} / \mathrm{mL})$ & 339 & 366 & 367 & 6.74 & 0.16 \\
\hline \multicolumn{6}{|c|}{ a-b Means within a row with different letters differ $(P<0.05)$. } \\
\hline
\end{tabular}


Table 6

Effects of dietary supplementation of Tongmai granule residue on blood biochemical parameters in sheep (45d)

\begin{tabular}{|c|c|c|c|c|c|}
\hline \multirow[t]{2}{*}{ Items $^{1}$} & \multicolumn{3}{|l|}{ Diet } & \multirow[t]{2}{*}{ SEM } & \multirow[t]{2}{*}{$P$-Value } \\
\hline & Control & $10 \%$ TGR & $15 \%$ TGR & & \\
\hline $\mathrm{GLU}(\mathrm{mmol} / \mathrm{L})$ & 4.04 & 3.83 & 3.89 & 0.05 & 0.19 \\
\hline BUN (mmol/L) & 5.78 & 5.54 & 4.85 & 0.22 & 0.21 \\
\hline TG (mmol/L) & 0.41 & 0.39 & 0.39 & 0.01 & 0.79 \\
\hline $\mathrm{TC}(\mathrm{mmol} / \mathrm{L})$ & 1.93 & 2.06 & 2.04 & 0.06 & 0.74 \\
\hline $\mathrm{HDL}-\mathrm{C}(\mathrm{mmol} / \mathrm{L})$ & 1.22 & 1.29 & 1.28 & 0.04 & 0.75 \\
\hline LDL-C (mmol/L) & 0.56 & 0.62 & 0.55 & 0.02 & 0.38 \\
\hline $\mathrm{TP}(\mathrm{g} / \mathrm{L})$ & 66.50 & 65.40 & 64.0 & 0.88 & 0.54 \\
\hline $\operatorname{ALB}(\mathrm{g} / \mathrm{L})$ & 35.9 & 37.06 & 36.07 & 0.31 & 0.25 \\
\hline GLB (g/L) & 31.08 & 29.3 & 30.2 & 0.95 & 0.77 \\
\hline $\lg A(u g / m L)$ & 53.3 & 55.00 & 56.3 & 0.99 & 0.49 \\
\hline $\operatorname{lgG}(\mathrm{ug} / \mathrm{mL})$ & 113 & 118 & 124 & 3.24 & 0.41 \\
\hline $\lg M(\mathrm{ug} / \mathrm{mL})$ & 324 & 323 & 335 & 4.28 & 0.50 \\
\hline \multicolumn{6}{|c|}{ a-b Means within a row with different letters differ $(P<0.05)$. } \\
\hline
\end{tabular}


Table 7

Effects of dietary supplementation of Tongmai granule residue on blood biochemical parameters in sheep (60d)

\begin{tabular}{|c|c|c|c|c|c|}
\hline \multirow{2}{*}{ Items $^{1}$} & \multicolumn{3}{|l|}{ Diet } & \multirow[t]{2}{*}{ SEM } & \multirow[t]{2}{*}{$P$-Value } \\
\hline & Control & $10 \%$ TGR & $15 \%$ TGR & & \\
\hline $\mathrm{GLU}(\mathrm{mmol} / \mathrm{L})$ & 4.11 & 3.92 & 4.06 & 0.08 & 0.59 \\
\hline $\mathrm{BUN} /(\mathrm{mmol} / \mathrm{L})$ & 5.48 & 5.42 & 5.35 & 0.14 & 0.95 \\
\hline TG (mmol/L) & 0.40 & 0.42 & 0.43 & 0.01 & 0.22 \\
\hline $\mathrm{TC}(\mathrm{mmol} / \mathrm{L})$ & 1.90 & 1.89 & 2.11 & 0.07 & 0.34 \\
\hline $\mathrm{HDL}-\mathrm{C}(\mathrm{mmol} / \mathrm{L})$ & $1.20^{\mathrm{b}}$ & $1.21^{\mathrm{b}}$ & $1.41^{\mathrm{a}}$ & 0.04 & 0.04 \\
\hline LDL-C (mmol/L) & 0.59 & 0.62 & 0.66 & 0.02 & 0.45 \\
\hline $\mathrm{TP}(\mathrm{g} / \mathrm{L})$ & 66.4 & 66.4 & 66.4 & 0.75 & 1.00 \\
\hline $\operatorname{ALB}(\mathrm{g} / \mathrm{L})$ & 36.8 & 35.6 & 34.50 & 0.56 & 0.27 \\
\hline GLB (g/L) & 29.60 & 30.8 & 32.00 & 1.00 & 0.65 \\
\hline $\lg A(u g / m L)$ & $53.8^{b}$ & $62.01^{a}$ & $63.9^{a}$ & 1.78 & 0.03 \\
\hline $\operatorname{lgG}(\mathrm{ug} / \mathrm{mL})$ & $131^{b}$ & $130^{b}$ & $190^{\mathrm{a}}$ & 8.07 & $<0.01$ \\
\hline $\operatorname{lgM}(\mathrm{ug} / \mathrm{mL})$ & $360^{b}$ & $371^{a b}$ & $391^{a}$ & 5.31 & 0.04 \\
\hline \multicolumn{6}{|c|}{ a-b Means within a row with different letters differ $(P<0.05)$. } \\
\hline
\end{tabular}

On day 30, dietary supplementation of 10\% TGR and 15\% TGR significantly increased the concentrations of IgG in serum $(P<0.05)$. The 15\% TGR group significantly reduced the concentrations of BUN $(P<0.05)$, and significantly increased the concentrations of $\operatorname{lgA}(P<0.05)$. There was no significant difference in serum GLU, TG, TC, HDL-C, LDL-C, TP, ALB, GLB and IgM concentrations between sheep in all dietary groups $(P>0.05)$.

Dietary TGR supplementation did not affect the blood biochemical parameters of sheep on day 45 of the feeding period $(P>0.05)$. However, the concentrations of BUN and TP decreased, and the concentrations of ALB, IgA, and IgG increased with a corresponding increase in TGR addition $(P>0.05)$.

Compared with the control group, dietary supplementation of $10 \%$ TGR and $15 \%$ TGR significantly increased the concentrations of $\operatorname{IgA}$ in serum $(P<0.05)$ on day 60 of the feeding period. When $15 \%$ TGR Loading [MathJax]/jax/output/CommonHTML/jax.js tions increased significantly $(P<0.05)$. The concentrations of 
$\lg$ in the 15\% TGR group were significantly higher than those in the control group $(P<0.05)$. There was no significant difference in other biochemical parameters $(P>0.05)$.

\section{Rumen Fermentation Parameters}

As shown in Table 8, TGR at $10 \%$ had no significant effect on rumen $\mathrm{pH}, \mathrm{NH}_{3}-\mathrm{N}, \mathrm{TVFA}$, acetic acid, propionic acid, and butyric acid concentrations as well as the acetic acid: propionic acid ratio in the rumen $(P>0.05)$. However, TGR at $15 \%$ significantly decreased the contents of acetic acid, propionic acid, butyric acid, and TVFA $(P<0.05)$, and significantly increased the $\mathrm{pH}, \mathrm{NH}_{3}-\mathrm{N}$ concentration, and the acetic acid: propionic acid ratio $(P<0.05)$ in the rumen.

Table 8

Effects of dietary supplementation of Tongmai granule residue on rumen fermentation parameters in sheep

\begin{tabular}{|llllll|}
\hline Items $^{1}$ & \multicolumn{2}{l}{ Diet } & & SEM & P-Value \\
\cline { 2 - 5 } & Control & $10 \%$ TGR & $15 \%$ TGR & & \\
\hline Rumen $\mathrm{pH}$ & $5.83^{\mathrm{b}}$ & $5.89^{\mathrm{b}}$ & $6.31^{\mathrm{a}}$ & 0.09 & 0.04 \\
\hline NH3-N (mg/dL) & $3.5^{\mathrm{b}}$ & $3.17^{\mathrm{b}}$ & $6.71^{\mathrm{a}}$ & 0.32 & $<0.01$ \\
\hline TVFA (mmol/L) & $90.8^{\mathrm{a}}$ & $94.7^{\mathrm{a}}$ & $59.2^{\mathrm{b}}$ & 5.96 & $<0.01$ \\
\hline Acetic acid (mmol/L) & $59.3^{\mathrm{a}}$ & $63.2^{\mathrm{a}}$ & $41.4^{\mathrm{b}}$ & 3.60 & $<0.01$ \\
\hline Propionic acid (mmol/L) & $22.6^{\mathrm{a}}$ & $21.6^{\mathrm{a}}$ & $10.7^{\mathrm{b}}$ & 2.04 & $<0.01$ \\
\hline Butyric acid (mmol/L) & $8.91^{\mathrm{a}}$ & $9.92^{\mathrm{a}}$ & $7.08^{\mathrm{b}}$ & 0.45 & $<0.01$ \\
\hline Acetic/Propionic acid & $2.63^{\mathrm{b}}$ & $2.97^{\mathrm{b}}$ & $3.89^{\mathrm{a}}$ & 0.21 & $<0.01$ \\
\hline a-b Means within a row with different letters differ $(P<0.05)$. & & \\
\hline 1 TVFA, total volatile fatty acids. & & & & \\
\hline
\end{tabular}

\section{Discussion}

Chinese herbal medicines are rich in nutrients and biologically active substances (Hossain et al., 2012). In addition to disease prevention, treatment, and enhancing the body's immunity, they can also improve feed conversion efficiency and promote animal growth and development (Qiao et al., 2016). Zhong et al. (2012) found that the addition of Astragalus polysaccharides to the diet increased the daily feed intake of lambs. Also, Qiao et al. (2016) found that the addition of Chinese herbal medicine increased the average daily gain, final body weight and feed conversion efficiency of Holstein dairy cows. The results of an Loading [MathJax]/jax/output/CommonHTML/jax.js e herbal medicine complex on the growth performance of 
simulated Taiwan country chickens showed that the complex at $0.3 \%$ increased both average daily weight gain and feed conversion ratio (Li et al., 2012). In contrast to the above experiments, the results of the present experiment indicated that dietary supplementation of $10 \%$ TGR did not affect the growth performance of sheep. However, $15 \%$ TGR supplementation decreased the average daily gain and increased the feed conversion ratio of sheep. This may have been related to the effect of puerarin, an active ingredient in Tongmai Granule, on weight loss and regulation of fat metabolism (Wang et al., 2017). However, its related mechanism needs further study.

Digestibility is a major indicator of the absorption and utilization of feed nutrients in animals, and is influenced by factors such as feed quality and animal feeding (Lin et al., 2006; Eiras et al., 2014). At present, there is little research on the effect of TGR on the apparent digestibility in ruminants. However, studies have shown that Chinese herbal medicine has the effect of enhancing animal body metabolism and improving nutrient digestibility and utilization. For example, the apparent digestibility of organic matter, crude protein and acid detergent fiber increased when heat stressed beef cattle diet was supplemented with a traditional Chinese medicine prescription (Song et al., 2014). In the present study, the digestibility of dietary CP, ADF and NDF decreased with an increase in TGR addition. Conversely, the digestibility of NDF in the 15\% TGR group was significantly lower than that in the control group. This result is inconsistent with that of Kim et al. (2002) who reported that the addition of dried Wormwood (Artemisia sp.; a traditional Chinese medicine) increased the feed intake and apparent digestibility of dry matter, total digestible nutrients, crude protein and crude fibre in sheep. The decreased digestibility in the present study may be due to the fact that Tongmai granules contain more fibrous substances. In this experiment, the addition of TGR increased the apparent digestibility of organic matter and crude fat. This agrees with findings by Qiao et al. (2012) who found that the addition of Fructus Ligustri Lucidi extract to sheep diet increased the digestibility of dry matter and organic matter and had no effect on CP, ADF, and NDF digestibility in sheep. This suggests that TGR can stimulate rumen degradation of non-structural carbohydrates in sheep.

Blood biochemical parameters usually reflect the health of an animal. These parameters are vital indicators of the physiological and nutritional status of animals (Alagawany and El-Hack, 2015). Blood glucose level is a direct response of animals' body to sugar absorption, transport, and metabolic homeostasis. In the current study, dietary inclusion of TGR had no significant effect on serum TC, TG and GLU concentrations. The results indicate that TGR supplementation has no adverse effects on the heart and liver, as well as the occurrence of hyperlipidemia in sheep, because TC and TG concentrations in the blood are strongly associated with cardiovascular diseases (Chanjula and Cherdthong, 2018). However, the serum GLU concentrations had a downward trend in the present study, which may be related to the activity of Pueraria, the main medicinal ingredient in TGR, in lowering blood glucose (Xie and Du, 2011).

The levels of serum LDL-C and HDL-C are important indicators that reflect the lipometabolic status in animals. HDL-C has a protective effect on blood vessels, which is generally considered to be good cholesterol and resistant to atherosclerosis, whereas LDL-C is prone to arteriosclerosis when it appears at 
serum LDL-C content from day 15 to day 60 of the experimental period. On day 15 , the $10 \%$ and $15 \%$ TGR groups significantly increased the HDL-C content, and on day 60 , the $15 \%$ TGR group significantly increased the HDL-C content, suggesting that dietary TGR addition could improve the cardiovascular system of sheep. This may be due to TGR's ability to activate blood circulation and treat diseases such as coronary heart disease and atherosclerosis.

BUN is an indicator of protein metabolism and dietary amino acid balance in animals. An increase in BUN levels reflects the impaired renal function/glomerular function (Blome et al., 2003; Tong et al., 2008). Our results indicated that serum BUN content was not affected by TGR addition except on day 30 of the experiment where the BUN content in the 15\% TGR group significantly reduced.. This shows that TGR has no negative effects on renal function. TP is composed of GLB and ALB. It has been found that serum TP content is an indicator for assessing the nutritional and metabolic status of an organism, and can reflect the health and immune levels in the organism. TP measurements are based on dietary protein content, liver metabolism and even protein loss caused by some lesions (Wang et al., 2011; Ortuno et al., 2001; Chen et al., 2016). In the present study, dietary addition of TGR had no significant effect on the total protein, albumin, and globulin content throughout the feeding period.

Immunoglobulin molecules (IgA, IgG and IgM) which are associated with humoral immunity are produced by the differentiation and proliferation of B lymphocytes. They are a class of globulins with antibody activity or chemical structure similar to antibody molecules, which can specifically bind to antigens and play an important role in regulating immune responses. The level of its content can reflect the status of the body's immune function ( $\mathrm{Li}$ et al., 2016; Li et al., 2018). In this study, Dietary TGR supplementation increased the content of serum IgM, IgA and IgG in sheep. This indicates that TGR can increase the number of lymphocytes and improve the rate of lymphocyte transformation. Furthermore, the increase in immunoglobulin content reflects the enhancement of humoral immune function in sheep.

Ruminal $\mathrm{pH}$ is an important indicator that reflects the level of rumen fermentation, and mainly affected by factors such as the type of diet and the amount of saliva secreted (Anantasook et al., 2013). Low ruminal $\mathrm{pH}$ has been shown to have a negative effect on fibre digestion and attachment of bacteria to plant cell walls (Cheng et al., 1984). In the present study, ruminal pH was significantly increased with the addition of $15 \%$ TGR and ranged from 5.83 to 6.31 . These values were optimal for rumen fermentation (Dalley et al., 1997). The increase of $\mathrm{pH}$ may be due to the decrease in rumen TVFA. This indicates that dietary addition of TGR has the potential to regulate the efficiency of nutrient digestion and the rumen fermentation pattern.

$\mathrm{NH}_{3}-\mathrm{N}$ is the main source of $\mathrm{N}$ in the process of microbial protein synthesis in the rumen, and plays a vital role in efficient microbial fermentation of feed. The level of ruminal $\mathrm{NH}_{3}-\mathrm{N}$ represents a balance between microbial protein synthesis and rumen protein degradation (Erdman et al., 1986; Cherdthong and Wanapat, 2013; Wang et al., 2016). Previous studies indicated that the optimal concentration of $\mathrm{NH}_{3}-\mathrm{N}_{\text {in }}$ the rumen is $0.35-29 \mathrm{mg} / \mathrm{dL}$ (Owens and Bergen, 1983). In the current study, the rumen $\mathrm{NH}_{3}-\mathrm{N}$ hormal range, which can meet the needs of rumen microbial 
growth. However, dietary inclusion of $15 \%$ TGR significantly increased the concentration of ruminal $\mathrm{NH}_{3}{ }^{-}$ $\mathrm{N}$. These findings indicate that supplementation of high levels of TGR may result in an increased $\mathrm{NH}_{3}-\mathrm{N}$ concentration, which in turn may affect microbial fermentation of feed in the rumen.

Volatile fatty acids are the main products of carbohydrate fermentation by various microorganisms in the rumen. They play the role of maintaining the rumen environment and providing energy for the animals' body. In the present study, dietary inclusion of 10\% TGR did not affect the concentration of TVFA but they had an increasing tendency. It shows that adding a suitable amount of TGR can help rumen microorganisms to produce more VFA, which can provide more energy for animals. There are some studies on the effects of herbal medicines on ruminal VFA formation. Qiao et al. (2012) observed higher concentrations of TVFA and propionate in sheep supplemented with Fructus Ligustri Lucidi extract at 300 or $500 \mathrm{mg} / \mathrm{kg}$ DM. Furthermore, Zhong et al. (2012) reported higher propionic acid concentration and lower acetic acid to propionic ratios in ruminal fluid when Astragalus polysaccharide and Astragalus membranaceus root was fed to weaned lambs. Also, Jin et al. (2018) found no changes in TVFA, propionate concentration and acetate: propionate proportion, but higher acetate and lower butyrate concentrations in growing lambs when diet was supplemented with $500 \mathrm{~g} / \mathrm{kg}$ Urtica cannabina. In contrast, results of the current study indicate that dietary inclusion of $15 \%$ TGR significantly decreased the concentration of acetic acid, propionic acid, butyric acid and TVFA, which may be related to the type, dosage and form of the residue. This indicates that excessive addition of TGR may adversely affect rumen microorganisms, and then reduce rumen fermentation function.

This study demonstrated that dietary supplementation of TGR can improve the apparent digestibility of crude fat and organic matter, and improve the anti-atherosclerosis ability and immune function of Doper x Small Tail Han hybrid female lambs. However, dietary supplementation of TGR up to $15 \%$ may have adverse effects on growth performance, slaughter performance, and digestibility of NDF, as well as rumen fermentation patterns. Therefore, under the conditions of the current experiment, it can be concluded that the addition of TGR up to $10 \%$ yielded the best results in improving performance in sheep. Further studies should be conducted to validate the effects of supplementing TGR to the diet and to determine the optimal feeding amounts in sheep.

\section{Abbreviations}

ADF (acid detergent fibre), ADFI (average daily feed intake), ADG (average daily gain), ALB (albumin), BUN (blood urea nitrogen), CP (crude protein), EE (ether extract), FCR (feed conversion ratio), GLB (globulin), GLU (glucose), HDL-C (high-density lipoprotein cholesterol), IgA (immunoglobulin A), IgG (immunoglobulin G), IgM (immunoglobulin M), LDL-C (low-density lipoprotein cholesterol), NDF (neutral detergent fibre), NRC (National Research council), OM (organic matter), TC (total cholesterol), TG (triglyceride), TGR (Tongmai granule residues), TP (total protein), TVFA (total volatile fatty acids).

\section{Declarations}




\section{Ethics approval and consent to participate Conflict of interest}

The animal experiments were conducted in accordance with the Guidelines for the Care and Use of Experimental Animals established and approved by the Laboratory Animal Management Committee of Jilin Agricultural University.

\section{Consent for publication}

Not applicable.

\section{Availability of data and materials}

The datasets used or analysed during the current study are available from the corresponding author on reasonable request.

\section{Competing interests}

The authors declare that they have no competing interests.

\section{Funding}

This study was supported by the National Key Research and Development Program of China (Grant No. 2016YFD0501209-03), and the National Natural Science Foundation of China (Grant No. 3177260).

\section{Authors' Contributions}

Zewei Sun and Qingzhen Zhong contributed to conception and design of the study. Pei Zhang and Abedin Abdallah performed the experiments. Wenge Cheng and Shiwen Sun performed the statistical analysis. Pei Zhang and Abedin Abdallah wrote the manuscript. All authors contributed to manuscript revision, read, and approved the submitted version.

\section{Acknowledgment}

Not applicable.

\section{References}


1. Alagawany, M., El-Hack, M.E.A., 2015. The effect of rosemary herb as a dietary supplement on performance, egg quality, serum biochemical parameters, and oxidative status in laying hens. J. Anim. Feed Sci. 24, 341-347. https://doi.org/10.22358/jafs/65617/2015

2. Anantasook, N., Wanapat, M., Cherdthong, A., Gunun, P., 2013. Effect of plants containing secondary compounds with palm oil on feed intake, digestibility, microbial protein synthesis and microbial population in dairy cows. Asian-australas. J. Anim. Sci. 26, 820-826.

https://doi.org/10.5713/ajas.2012.12689

3. Blome, R.M., Drackley, J.K., McKeith, F.K., Hutjens, M.F., McCoy, G.C., 2003. Growth, nutrient utilization, and body composition of dairy calves fed milk replacers containing different amounts of protein. J. Anim Sci. 81, 1641-1655.

https://doi.org/10.2527/2003.8161641x

4. Chanjula, P., Cherdthong, A., 2018. Effects of spent mushroom Cordyceps militaris supplementation on apparent digestibility, rumen fermentation, and blood metabolite parameters of goats. J. Anim. Sci. 96, 1150-1158. https://doi.org/10.1093/jas/skx079

5. Chen, C.Y., Zu, Y.G., Fu, Y.J., Luo, M., Zhao, C.J., Wang, W., Zhao, B.S.,Li, J., Efferth, T., 2011. Preparation and antioxidant activity of Radix Astragali residues extracts rich in calycosin and formononetin. Biochem. Eng. J. 56, 84-93. https://doi.org/10.1016/j.bej.2011.04.015

6. Cheng, K.J., Stewart, C.S., Dinsdale, D., Costerton, J.W., 1984. Electron microscopy of bacteria involved in the digestion of plant cell walls. Anim. Feed Sci. Technol. 10, 93-120. https://doi.org/10.1016/0377-8401(84)90002-6

7. Chen, Y.B., Hu, J., Lv, Q.J., Liu, L.J., Wen, L.F., Yang, X.K., Zhao, H.H., 2016. The effects of Natucin CNatucin $\mathrm{P}$ mixture on blood biochemical parameters, antioxidant activity and non-specific immune responses in tilapia (Oreochromis niloticus). Fish Shellfish Immun. 55, 367-373. https://doi.org/10.1016/j.fsi.2016.06.016

8. Cherdthong, A., Wanapat, M., 2013. Manipulation of in vitro ruminal fermentation and digestibility by dried rumen digesta. Livest. Sci. 153, 94-100. https://doi.org/10.1016/j.livsci.2013.02.008

9. Dalley, D.E., Isherwood, P., Sykes, A.R., Robson, A.B., 1997. Effect of in vitro manipulation of pH on magnesium solubility in ruminal and caecal digesta in sheep. J. Agric Sci. 129, 107-111. https://doi.org/10.1017/s0021859697004486

10. Eiras, C.E., Barbosa, L.P., Marques, J.A., Araújo, F.L., Lima, B.S., Zawadzki, F., Perotto, D., Prado, I.N., 2014. Glycerine levels in the diets of crossbred bulls finished in feedlot: apparent digestibility, feed intake and animal performance. Anim. Feed Sci. Technol. 197, 222-226.

https://doi.org/10.1016/j.anifeedsci.2014.07.004

11. Erdman, R.A., Proctor, G.H., Vandersall, J.H., 1986. Effect of rumen ammonia concentration on in situ rate and extent of dinection of feedctuffs. J. Dairy Sci. 69, 2312-2320.

Loading [MathJax]/jax/output/CommonHTML/jax.js 
https://doi.org/10.3168/jds.S0022-0302(86)80670-1

12. Gong, J., Yin, F., Hou, Y., Yin, Y., 2014. Chinese herbs as alternatives to antibiotics in feed for swine and poultry production: potential and challenges in application. Can. J. Anim. Sci. 94, 223-241. https://doi.org/10.4141/cjas2013-144

13. Guo, F.C., Kwakkel, R.P., Soede, J., Williams, B.A., Verstegen, M.W.A., 2004. Effect of a Chinese herb medicine formulation, as an alternative for antibiotics, on performance of broilers. Brit. Poultry Sci. 45, 793-797. https://doi.org/10.1080/00071660400012741

14. Hossain, M.E., Ko, S.Y., Park, K.W., Firman, J.D., Yang, C.J., 2012. Evaluation of green tea by-product and green tea plus probiotics on the growth performance, meat quality and immunity of growing finishing pigs. Anim. Prod. Sci. 52, 857-866. https://doi.org/10.1071/AN11141

15. Jin, Y.M., Jiang, C., Zhang, X.Q., Shi, L.F., Wang, M.Z., 2018. Effect of dietary Urtica cannabina on the growth performance, apparent digestibility, rumen fermentation and gastrointestinal morphology of growing lambs. Anim. Feed Sci. Technol. 243, 1-9. https://doi.org/10.1016/j.anifeedsci.2018.06.014

16. Kim, J.H., Kim, C.H., Ko, Y.D., 2002. Influence of dietary addition of dried wormwood (Artemisia sp.) on the performance and carcass characteristics of Hanwoo steers and the nutrient digestibility of sheep. Asian-australas. J. Anim. Sci. 15, 390-395. https://doi.org/10.5713/ajas.2002.390

17. Lin, H.Z., Li, Z.J., Chen, Y.Q., Zheng, W.H., Yang, K., 2006. Effect of dietary traditional Chinese medicines on apparent digestibility coefficients of nutrients for white shrimp Litopenaeus vannamei, Boone. Aquaculture 253, 495-501. https://doi.org/10.1016/j.aquaculture.2004.11.048

18. Li, T.Y., Yang, J.R., Yeh, H.S., Lien, T.F., 2012. Effects of supplemental various levels of Chinese traditional herbal medicine complex on the growth performance, immunity, serum traits and meat quality of simulated Taiwan country chickens. J. Anim. Sci. Adv. 2, 166-176.

19. Li, Y., Wang, Y.Z., Ding, X., Zhang, Y.G., Xue, S.C., Lin, C., Xu, W.B., Dou, X.J., Zhang, L.Y., 2016. Effects of Acremonium terricola culture on growth performance, antioxidant status and immune functions in weaned calves. Livest. Sci. 193, 66-70. https://doi.org/10.1016/j.livsci.2016.09.009

20. Li, Y., Sun, Y.K., Li, X., Zhang, G.N., Xin, H.S., Xu, H.J., Zhang, L.Y., Li, X.X., Zhang, Y.G., 2018. Effects of Acremonium terricola culture on performance, milk composition, rumen fermentation and immune functions in dairy cows. Anim. Feed Sci. Technol. 240, 40-51.

https://doi.org/10.1016/j.anifeedsci.2018.03.015

21. Meng, F., Yang, S., Wang, X., Chen, T., Wang, X., Tang, X., Zhang, R., Shen, L., 2017. Reclamation of Chinese herb residues using probiotics and evaluation of their beneficial effect on pathogen infection. J. Infect. Public Heal. 10, 749-754. https://doi.org/10.1016/j.jiph.2016.11.013

22. NRC, 2010. Guide for the care and use of laboratory animals. National Academies Press.

23. Ortuno, J., Esteban, M.A., Meseguer, J., 2001. Effects of short-term crowding stress on the gilthead seabream (Sparus aurata L.) innate immune response. Fish Shellfish Immun. 11, 187-197. https://doi.org/10.1006/fsim.2000.0304 
24. Owens, F.N., Bergen, W.G., 1983. Nitrogen metabolism of ruminant animals: historical perspective, current understanding and future implications. J. Anim. Sci. 57, 498-518.

25. Qiao, G.H., Zhou, X.H., Li, Y., Zhang, H.S., Li, J.H., Wang, C.M., Lu, Y., 2012. Effect of several supplemental Chinese herbs additives on rumen fermentation, antioxidant function and nutrient digestibility in sheep. J. Anim. Physiol. Anim. Nutr. 96, 930-938. https://doi.org/10.1111/j.14390396.2011.01211.x

26. Qiao, G., Shao, T., Yang, X., Zhu, X., Li, J., Lu, Y., 2016. Effects of supplemental Chinese herbs on growth performance, blood antioxidant function and immunity status in Holstein dairy heifers fed high fibre diet. Ital J Anim Sci 12, 121-127. https://doi.org/10.4081/ijas.2013.e20

27. Shi, L., Yu, H.S., Jin, F.X., 2010. Study on Tanshinone extracted from Salvia miltiorrhiza Bge. Dregs. Agric. Sci. Technol. 11, 103-106. https://doi.org/10.16175/j.cnki.1009-4229.2010.01.005.

28. Song, X., Luo, J., Fu, D., Zhao, X., Bunlue, K., Xu, Z., Qu, M., 2014. Traditional chinese medicine prescriptions enhance growth performance of heat stressed beef cattle by relieving heat stress responses and increasing apparent nutrient digestibility. Asian-australas. J. Anim. Sci. 27, 15131520.

https://doi.org/10.5713/ajas.2014.14058

29. Tong, D., Wang, J., Mu, P., Dong, Q., Zhao, B., Liu, W., Zhao, J., Li, L., Zhou T., 2008. Analysis of several serum enzymes and blood urea nitrogen of swainsonine-HSA immunized goats[J]. Anim. Feed Sci. Technol. 142, 74-88. https://doi.org/10.1016/j.anifeedsci.2007.07.007

30. Wang, C., Liu, Q., Guo, G., Huo, W.J., Ma, L., Zhang, Y.L., Pei, C.X., Zhang, S.L., Wang, H., 2016. Effects of dietary supplementation of rumen-protected folic acid on rumen fermentation, degradability and excretion of urinary purine derivatives in growing steers. Arch. Anim. Nutr. 70, 441-454. https://doi.org/10.1080/1745039X.2016.1233677

31. Wang, F.R., Zhang, Y., Yang, X.B., Liu, C.X., Yang, X.W., Xu, W., Liu, J.X., 2017. Rapid Determination of 30 Polyphenols in Tongmai Formula, a Combination of Puerariae Lobatae Radix, Salviae Miltiorrhizae Radix et Rhizoma, and Chuanxiong Rhizoma, via Liquid Chromatography-Tandem Mass Spectrometry. Molecules 22, 1-10. https://doi.org/10.3390/molecules22040545

32. Wang, J.H., Wu, C.C., Feng, J., 2011. Effect of dietary antibacterial peptide and zinc-methionine on performance and serum biochemical parameters in piglets. Czech J. Anim. Sci. 56, 30-6.

33. Wang, P., Zhan, S., Yu, H., Xue, X., Hong, N., 2010. The effects of temperature and catalysts on the pyrolysis of industrial wastes (herb residue). Bioresource Technol. 101, 3236-3241. https://doi.org/10.1016/j.biortech.2009.12.082

34. Wang, R., Li, D., Bourne, S., 1998. Can 2000 years of herbal medicine history help us solve problems in the year 2000. Alltechs annual symposium. 14, 168-184.

35. Wu, S., Zhou, Q.L., Yang, X.W., 2017. UFLC-DAD-ESI-IT-TOFMSn Analysis on Biotransformation of Tongmai Formula Incubated with Human Intestinal Bacteria. Chin. Herb. Med. 9, 258-266. 
36. Xie, W., Du, L., 2011. Diabetes is an inflammatory disease: evidence from traditional Chinese medicines. Diabetes Obes. Metab. 13, 289-301.

https://doi.org/10.1111/j.1463-1326.2010.01336.x

37. Zhu, Z.Y., Li, Y., Sun, H.Q., Chen, L.J., TANG, Y.L., Liu, X.C., Zhang, Y.M., 2016. Screening of Cordyceps strains and optimization of its solid-state fermentation conditions on bioconversion of Astragalus residue. Cell. Chem. Technol. 50, 257-263.

38. Zhong, R.Z., Yu, M., Liu, H.W., Sun, H.X., Cao, Y., Zhou, D.W., 2012. Effects of dietary Astragalus polysaccharide and Astragalus membranaceus root supplementation on growth performance, rumen fermentation, immune responses, and antioxidant status of lambs. Anim. Feed Sci. Technol. 174, 6067. https://doi.org/10.1016/j.anifeedsci.2012.02.013 